\title{
Elämäkerrallista helskyttelyä
}

\section{Panu Rajala: Virvatuli: Eino Leinon elämä. Helsinki: WSOY, 2017, 596 s.}

Millainen on hyvä elämäkerta? Kirjoittajalla tulee ensinnäkin olla laajaan aineistoon pohjautuva perusteltu oma näkemys kohdehenkilöstä, ja hänen on lisäksi hyvä keskustella avoimesti aikaisempien elämäkerrallisten tulkintojen kanssa selkeästi osoittaen, missä hän irrottautuu näistä. Kuten Jane Austenista tehtyjä elämäkerrallisia esityksiä tutkinut Kathryn Sutherland on todennut, biografinen työ on ennemminkin bibliografiaa - kaivautumista erilaisten tekstikerrostumien läpi, etenkin jos kohdehenkilö on tunnettu historiallinen henkilö ja hänestä on kirjoitettu ajan mittaan useampia elämäkerrallisia esityksiä (Sutherland 2005, 63; 103). Usein henkilön ensimmäisessä elämäkerrassa kerrotut perustarinat toistuvat elämäkerrasta toiseen. Uutta elämäkertaa kirjoittaessa on siis hyvä tarkastella, ovatko kertomukset tekstuaalisten kerrostumien myötä ryöstäytyneet elämään omaa elämäänsä. Viime vuosina monissa elämäkerroissa on paneuduttu juuri myyttien purkamiseen.

On myös tärkeää, että elämäkerran kirjoittaja osoittaa tuntevansa aikakauden keskeiset yhteiskunnalliset ja kulttuurihistorialliset tapahtumat ja aatteet, joilla on olennaista merkitystä kohdehenkilön elämän ja työn kannalta. Kirjailijaelämäkerran kirjoittajan on hyvä olla perillä kohdehenkilönsä keskeisistä vaikutteista ja kirjallisista keskustelukumppaneista - ainakin siltä osin, kun kirjailijan tuotannosta on tehty perustutkimusta, jossa näitä yhteyksiä on osoitettu.

Panu Rajalan vuonna 2017 ilmestynyt Eino Leinon elämäkerta Virvatuli on ongelmallinen näiden keskeisten odotusten osalta. Teoksen loppuun sijoitetussa johdantomaisessa kirjoituksessa Rajala kertoo pyrkimyksekseen rakentaa uudenlaista Leino-kuvaa, mutta heti perään hän toteaa, että mikäpä toisaalta ei nykylukijalle olisi Leinossa uutta. Rajala on oikeassa siinä, että useimmille nykylukijoille Leino on tuntematon - kirjailijana, kääntäjänä ja suomalaisen kirjallisuuden uranuurtajana. Sen sijaan Leinon lemmenkipeys, viinanhimo ja boheemi kodittomuus "tiedetään", ne ovat rakennusaineksia Leino-myytille, joka peittää alleen kirjailija-Leinon. Siksi onkin erikoista, että Rajala ryhtyy Leinon nuoruusvuosista alkaen vahvistamaan tuttua julkisuuskuvaa. Loppusanoissa luvattu stereotypioiden "sijoiltaan kääntäminen" jääkin toteutumatta, ja sen sijaan toistetaan myyttistä kuvaa Leinosta rakastumisia tarvitsevana alkoholistina, joka kirjoitti runoja lähinnä ihastuksilleen.

Rajalan elämäkerrasta hahmottuva kirjailija Leino on kielellinen superlahjakkuus, joka lukee jopa venäjää "luontaisella kielitajullaan", mutta toisaalta kielellinen virtuositeetti käännetään myös hänen heikkoudekseen, sillä pitkin Leinon tuotantoa Rajala syyttää tätä hutiloinnista ja helskyttelystä. Rajala nos- 
taa esiin lähinnä negatiivisia arvioita Leinon teoksista ja usein vahvistaa olevansa kriittisen arvioijan kanssa samaa mieltä. Rajala päättelee tekstistä myös Leinon mielentilan kirjoitustyön keskellä. Esimerkiksi Onnen orja -romaanista Rajala (259) kirjoittaa: "Kaikesta näkyy, että kirjoittajalla on jo tuskastunut kiire saada romaanisarjansa päätökseen eikä hän enää piittaa vähääkään tyylin tai rakenteen tai johdonmukaisuuden kysymyksistä”. Oliko Leino todella näin huono kirjailija?

Rajalan luennat Leinon teoksista jättävät jälkeensä enemmän ihmetystä kuin oivalluksia. Helkavirsien ensimmäisen sarjan (1903) sinänsä mainiosta liikkeen ja fyysisyyden havainnosta Rajala (96) päättelee: "Nuori Leino olisi pitänyt länkkäreistä, jos elokuvia olisi ollut”. Rajala ei pyrikään lähilukemaan teoksia eikä tutkimusta juurikaan käytetä luennan tukena.

Kaikkein ohuimmaksi elämäkerrassa jää Leinon isänmaallisten runojen ja poliittisten pakinoiden tulkinta. Rajala itsekin korostaa, että Leinon tekstien ymmärtämiseksi on tunnettava ajan poliittiset "virtaukset ja vivahteet", mutta juuri epookin tuntemuksessa hän tekee suurimmat kömmähdyksensä.

Rajalan mukaan kansallisen yhteishengen luomiselle syntyi "akuutti tarve" suurlakon jälkeen, siis loppuvuonna 1905. Aiemmin asialla olivat olleet J. H. Erkko ja Juhani Aho, Rajala toteaa, mutta nyt myös Leino "riensi peitsi ojossa kärkeen, päin sorron tuulta taistelemaan" (136). Tosiasiassa Leino oli ollut nuorsuomalaisten ja perustuslaillisten keskeinen ajankohtaisrunoilija jo koko ensimmäisen sortokauden ajan, jonka katsotaan päättyneen suurlakkoon. Heti 1899 helmikuun manifestin levittyä yleiseen tietoisuuteen Leino julkaisi Päivälehdessä kuuluisan venäläistämispainetta kuvaavan runon "Helsinki sumussa" ja samana vuonna ilmestyneen Ajan aalloilta -kokoelman keskeinen aihe olivat juuri ajan poliittiset tunnelmat. Isänmaalliset runot olivat tärkeä osa kulttuurista vastarintatyötä, jota olen itse kuvannut teoksessani Kultakauden maanalainen vastarinta: Sortokauden taisto isänmaan ja sananvapauden puolesta (2017) ja Leino oli eturintamassa koko ensimmäisen sortokauden ajan, kunnes pettyi suomalaiseen kansaan ja pakeni toisen sortokauden alkaessa ulkomaille.

Kirjallisuuden- ja taiteentutkimuksen alan tutkimuksille ja elämäkerroille on varsin tyypillistä jättää tarkastelematta ajan yhteiskunnallisen kuohunnan vaikutusta tekijän elämänvaiheisiin ja teoksiin, mikä johtunee jonkinlaisesta formalistisesta havainnon rajauksesta. Rajalan kunniaksi on sanottava, että hän yrittää kyllä. Mutta kun sekä tapahtumien ajoituksessa että poliittisten asetelmien ymmärtämisessä on karkeita virheitä, lopputulos on hämmentävä.

Rajala (85) esimerkiksi kirjoittaa:

Runo ["Kun kello seisoo"] oli suunnattu passiivista myöntyväisyyssuuntaa vastaan. Venäjän sortotoimet, kuten laittomiksi tulkitut asevelvollisuuskutsunnat, kuohuttivat mieliä. Leino vaati vastarinnalle vahvaa johtajaa. Passiivisen ja sitten kovenevan perustuslaillisen vastarinnan keulahahmo 
Leo Mechelin ei ilmeisesti kelvannut Leinolle. Vuonna 1903 saatiin maahan sitten vahva taantumuksellinen johtaja, kenraalikuvernööri Bobrikov. Kello alkoi käydä taaksepäin, vastarinta terästyi.

Bobrikov oli itse asiassa aloittanut Suomen kenraalikuvernöörinä jo kesällä 1898 ja ryhtynyt voimallisesti toteuttamaan Suomen venäläistämistä. Erityisesti Suomen kulttuurinen lähentäminen emämaahan oli Bobrikoville tärkeää, ja hän oli vuoteen 1903 mennessä hyökännyt paitsi koulutusta ja oikeuslaitosta, myös suomalaista lehdistöä ja sananvapautta vastaan ja useita lehtiä oli jo lakkautettu. Ruotsalaisen puolueen johtaja Leo Mechelin puolestaan kohosi nopeasti helmikuun manifestin jälkeen perustuslaillisen - siis nuorsuomalaisten ja ruotsinmielisten - vastarinnan arvostetuksi johtajaksi, jonka Bobrikov karkotti maasta keväällä 1903 saatuaan diktaattorinoikeudet. Vastarinta lamaantui ja etenkin passiivisuuteen turhautuneet nuoret alkoivat taipua aktiivisen, väkivaltaisen vastarinnan tielle. Myöntyväisyyssuunta - eli Yrjö Sakari Yrjö-Koskisen ja Johan R. Danielsonin johtama Suomalainen puolue eli suomettarelaiset - puolestaan vastusti kaikenlaista vastarintaa, ja Bobrikov käytti taitavasti hyväkseen Suomen sisäistä poliittista polarisoitumista. Rajalan esimerkkinään käyttämä Leinon runo "Kun kello seisoo" oli kuitenkin julkaistu jo vuonna 1896 kokoelmassa Tarina suuresta tammesta eikä sillä näin ollen ole yhteyttä sortovuosien poliittisiin asetteluihin.

Leinon näkyvä asema keskeisenä perustuslaillisten ajankohtaisrunoilijana ja teräväkynäisenä poliittisena pakinoitsijana vaikutti luonnollisesti myös suomettarelaisiin kritiikkeihin, mitä Rajala ei juurikaan avaa. Hän ei myöskään selvitä sen tarkemmin suomettarelaisten kirjallisen johtohahmon Maila Talvion ja Eino Leinon välirikkoa. Vaikka Rajala toteaa, että näistä tuli toistensa poliittiset viholliset, kuvaa hän Leinon etääntymisen syyksi sen, että tämä "kavahti Mailan impulsiivista lähentelyä" (268). Talvio löysi Leinon jälkeen uudeksi suojatikseen V. A. Koskenniemen, joka ryhtyi tovereineen systemaattisesti hyökkäilemään Leinoa vastaan. Talvion ja Koskenniemen poliittinen aatemaailma jatkoi samansuuntaista kehitystä toiseen maailmansotaan saakka, ja olisi jo aika, että näistä linjoista saataisiin myös kirjallisuudentutkimuksen puolella perusteellista uutta tutkimusta.

Poliittisten kehityslinjojen tarkastelu ja Leinon yhteiskunnallisen ajattelun konteksualisoiminen ovat olennaisia myös tulkittaessa Leinon suhdetta sisällissotaan. Rajala ei kuitenkaan tulkitse Leinon pettymyksen taustoja suhteessa aiempaan poliittiseen historiaan, vaan määrittelee tämän punaisen terrorin tuomitsevat tekstit ykskantaan asettumiseksi valkoisten puolelle. Rajalan mukaan aiemmat maltilliset tulkinnat ovat olleet väärässä unohtaessaan valkoisen "vapaussoturin juhlarunot" ja pitäessään "Leinon nuorsuomalaista edistyksellisyyttä [--] hengissä vastoin runoilijan omia irtiottoja" (562). Rajalan tulkinta ei ole uusi, sillä myös Hannu Mäkelä $(1997,208)$ määrittelee Leino-elämäkerrassaan tämän sympatioiden olleen valkoisten puolella. Leinon 
kannanotoissa on kuitenkin kritiikkiä niin valkoisia kuin punaisiakin kohtaan, eikä Leinolle sisällissodan jälkeen myönnetty toviin ainuttakaan apurahaa - jos Leino olisi ollut kynältään vitivalkoinen, kuten Rajala haluaa esittää, miksi voittajat käänsivät hänelle sodan jälkeen selkänsä?

Rajalan esitystapa saakin pohtimaan, onko tarkoitus ollut etsiä Leinosensaatioita, ilmestyihän elämäkerta juuri sisällissodan muistokevään aattona. Samaan viittaisi elämäkerran johdannoksi nostettu kuvaus Leinon "piileskelystä" sisällissodan aikana. Tämä johdantoluku on muuten lyhennelmä teoksessa myöhemmin esiintyvästä sisällissotajaksosta, mikä on varsin erikoinen toimituksellinen ratkaisu. Joka tapauksessa suosittelisin Leinon sisällissotasuhteesta kiinnostuneita perehtymään ennemmin Esko Piipon teoksiin Eino Leino ja isänmaa (2017) sekä Eino Leino ja 1918 (2018), joissa lähestytään aihetta Leinon omien tekstien ja asiantuntevan taustoituksen kautta.

Suurimpana elämäkerrallisena löydöksenään Rajala pitää Leinon vahvistunutta syfilis-diagnoosia. Tässä toteaisin samoin kuin Hannu Mäkelä $(1997,283)$ jo aikanaan omassa elämäkerrassaan: sukupuolitauti tai ei - ei se ole tärkeää. Leino kuoli elettyään ihmisen mitan. Kiinnostavampaa on se, mitä merkittävää hän teki elämänsä aikana, mutta siitä Rajalan teos ei juurikaan kerro.

\section{Minna Maijala}

\section{Aineisto}

Maijala, Minna. Kultakauden maanalainen vastarinta: Sortokauden taisto isänmaan ja sananvapauden puolesta. Helsinki: Otava, 2017.

Mäkelä, Hannu. Eino Leino-Elämä ja runo. Helsinki: Otava, 1997.

Piippo, Esko. Eino Leinoja 1918. Kajaani: Kainuun Eino Leino -seura, 2018.

Piippo, Esko. Eino Leino ja isänmaa. Kajaani: E. Piippo, 2017.

Sutherland, Kathryn. Jane Austen's Textual Lives from Aeschylos to Bollywood. Oxford: Oxford University Press, 2005. 